\title{
Dusk- 1525
}
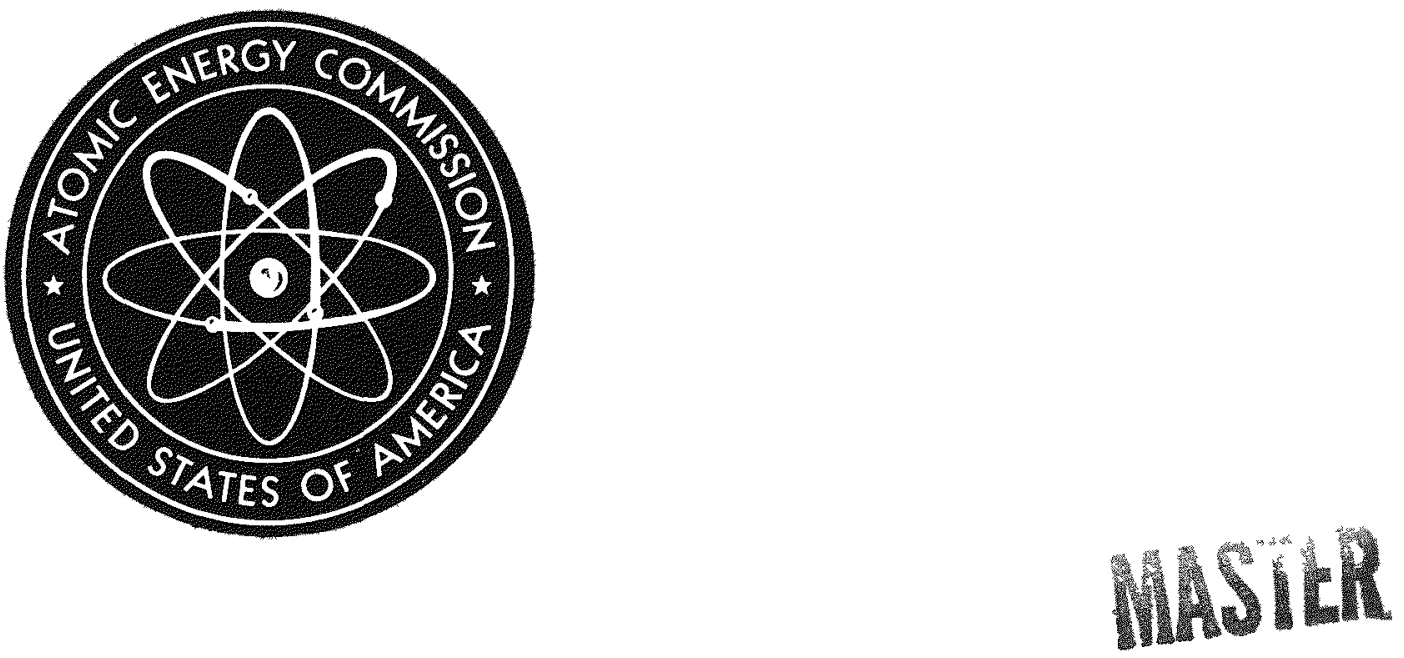

HASL-235

\section{PLUTONIUM IN SOIL AROUND THE ROCKY FLATS PLANT}

August 1, 1970

Health and Safety Laboratory USAEC

New York, New York

This documeat is

PUBLICLY RELEASABLE theak kiven Atuthorting Oricial

Date: 1130109 


\section{DISCLAIMER}

This report was prepared as an account of work sponsored by an agency of the United States Government. Neither the United States Government nor any agency Thereof, nor any of their employees, makes any warranty, express or implied, or assumes any legal liability or responsibility for the accuracy, completeness, or usefulness of any information, apparatus, product, or process disclosed, or represents that its use would not infringe privately owned rights. Reference herein to any specific commercial product, process, or service by trade name, trademark, manufacturer, or otherwise does not necessarily constitute or imply its endorsement, recommendation, or favoring by the United States Government or any agency thereof. The views and opinions of authors expressed herein do not necessarily state or reflect those of the United States Government or any agency thereof. 


\section{DISCLAIMER}

Portions of this document may be illegible in electronic image products. Images are produced from the best available original document. 


\section{LEGAL NOTICE}

This report was prepared as an account of Government sponsored work. Nelther the United States, nor the Commission, nor any person acting on behalf of the Commission:

A. Makes any warranty or representation, expressed or implied, with respect to the accuracy, completeness, or usefulness of the information contained in this report, or that the use of any information, apparatus, method, or process disclosed in this report may not infringe privately owned rights; or

B. Assumes any liabilities with respect to the use of, or for damages resulting from the use of any information, apparatus, method, or process disclosed in this report.

As used in the above, "person acting on behalf of the Commission" includes any employee or contractor of the Commission, or employee of such contractor, to the extent that such employee or contractor of the Commission, or employee of such contractor prepares, disseminates, or provides access to, any information pursuant to his emaployment or contract with the Cornmission, or his employment with such contractor.

This report has been reproduced directly from the best available copy.

Printed in USA. Price $\$ 3.00$. Available from the Clearinghouse for Federal Scientific and Technical Information, $\mathrm{Na}$ tional Bureau of Standards, U. S. Department of Commerce, Springfield, Virginia 22151. 


\section{LEGAL NOTICE}

This report was prepared as an account of Government sponsored work. Neither the United States, nor the Cornmssion, nor any person acting on behalf of the Commission:

A. Makes any warranty or representation, expressed or implied, with respect to the accuracy, completeness, or usefulness of the information contained in this report, or that the use of any information, apparatus, method, or process disclosed in this report may not infringe privately owned rights; or

B. Assumes any liabilities with respect to the use of, or for damages resulting from the use of any information, apparatus, method, or process disclosed in this report.

$A B$ used in the above, "porson acting on behatf of the Commission" includes any employee or contractor of the Commission, or employee of such contractor, to the extent that such employee or contractor of the Commission, or employee of such contractor prepares, disseminates, or provides access to, any information pursuant to his employment or contract with the Commission, or his employment with such contractor.

August I, 1970

U. S. Atomi. Energy Commission Health and Safety Laboratory New Yowk, New York 


\section{TABLE OF CONTENTS}

SUMMARY OF FINDINGS

INTRODUCT ION

Bre operational survey

Sampling site location

SOIL SAMPLING

RADIOCHEMICAL ANALYSIS

Sample preparation

Radiochemical procedure

RESULTS

QUALITY CONTROL

Blanks and low level samples

Analytical precision

Analytical accuracy

Representivity of soil sampling

DISCUSSION

Distribution with depth

Inventory

Source of contamination 


\section{LIST OF TABLES}

No.

1

2

3

4

5

6

A

B

2

3

4

HASI Soil Sampling sites in the Rocky Flats Area Complete Dissolution Versus Leaching

Total Plutonium Deposited at soil sampling sites in the Rocky Flats Area

Depth Distribution of Plutonium

Blank and Low Level Samples

Mean Percent Deviation Between Aliquots

Analyses of Reference Samples

Daplicate Soil Sampling in the Rocky Flats Area

Analytical Results: Rocky flats Soils

Analytical Results: Reference Soils

\section{IIST OF FIGURES}

Average Wind Rose at Rocky Flats Plant, 1953 - 1970

Average Hourly Winds During Fire of May 11. 1969

Average Hourly Winds During Fire which began on September 11, 1957

HASL Soil Sampling Sites

Plutonium-239 Contours around Rocky Flats 


\section{SUMMARY OF FINDINGS}

Soil samples were collected to a depth of $20 \mathrm{~cm}$ at 33 sites extending as far as 40 miles from the Dow Chemical Co.'s Rocky Flats plant in Colorado. Deposition concentrations of Pu-239 as high as $2000 \mathrm{mCi} / \mathrm{km}^{2}$ were found off the plant site but these high concentrations decreased rapidy with distance. The contamination pattern extends eastward from the plant in the direction of the resultant wind vector and has virtually no westward component. The pattern is incompatible with the wind direction on the day of the May 11, 1969 fire. Leaking barrels of plutonium laden cutting oil stored in the southeast corner of the plant are considered the likely source of the contaminant.

Three $\mathrm{mCi} / \mathrm{km}^{2}$ of $\mathrm{Pu}-239$ is the lowest contour readily aiscernible in the contamination pattern and extends about 8 miles east and southeast of the plant. The inventory of Rocky Flats Pu-239 within the

$3 \mathrm{mCl} / \mathrm{km}^{2}$ contour but excluding AEC controlled land is $2.6 \mathrm{Ci}$. The extent of the Rocky Flats Pu-239 beyond this contour is difficult to determine because the deposition of $\mathrm{Pu}-239$ from nuclear weapon tests fallout is not precisely known in the Denver area. Our best estimate of the cumulative fallout $\mathrm{Pu}-239$ is $1.5 \mathrm{mCi} / \mathrm{km}^{2}$ based upon a 1965 
soil sample from nearby Derby, Colorado. The most distant sites at 40 miles to the east and north of the plant show a slightly higher value of $2.0 \mathrm{mCi} / \mathrm{km}^{2}$. The intervening sites average $2.4 \mathrm{mCi} / \mathrm{km}^{2}$. If the extreme and unlikely assumption is made that the entire area Iying 40 miles to the east and north of the plant is contaminated with $1 \mathrm{mCi} / \mathrm{km}^{2}$, an additional $3.2 \mathrm{Ci}$ of Rocky Flats plutonium could have been released to these remote areas. Sr-90 analyses of the Rocky Flats soils and other studies are in process which might resolve this uncertainty in the remote areas, but additional sampling may be required to thoroughly solve the problem.

The plutonium has been shown to move down into the soil as far as $13 \mathrm{~cm}$, although the distribution shows wide variability apparently depending upon soil chemistry. In several cases there is as much as $60 \%$ of the total plutonium below $5 \mathrm{~cm}$. The analytical precision of aliquoting the sample and analysis was shown to be $\pm 20 \%$. Analyses of duplicate samples taken from the same location showed similar precision indicating that the soil sampling was representative of the area studied. 


\section{$I N T R O D U C T I O N$}

On May 11, 1969 a serious fire broke out at the Atomic Energy Commission's plutonium processing plant at Rocky Flats, Colorado(1). Stimulated by the possible release of plutonium to the environment by this fire, Dr. Martell demonstrated the presence of Rocky Flats plutonium in soil around the plant (2). On further investigation it appeared that there were three other plausible sources for this offsite plutonium, i.e.:

1. the September 11, 1957 fire;

2. leaking drums of contaminated cutting oil in a storage area in the southeast corner of the plant complex:

3. a chronic low level stack effluent.

Because of our expertise in soil sampling for radionuclides and their analyses. HASL was invited to perform an initial study of the distribution of $\mathrm{Pu}-239$ in soil around the plant. The objectives of this initial study were to:

(a) confirm and broadly quantify the levels of Rocky Flats plutonium in the soil:

(b) define the maximum distances from the plant at which significant Rocky Flats plutonium could be detected; and

(c) if possible, determine the quantity of Rocky flats plutonium in the soil off-site; that is, off AEC property. 


\section{Preoperational Survey}

To assist us in designing a sampling program, we requested

Dr. I. Van der Hoven, Chief, ERL, ESSA, Washington, D.C. to make a meteorological examination of the Rocky Flats area. In response C. R. Dickson and G. E. Start surveyed the area during the week of January 26, 1970, and in their memorandum to the files (3) made the following observations and recommendations:

1. More if not most of the Rocky Flats plutonium in the soil around the plant was contributed by the 1957 fire and the leakage from the contaminated drums.

2. These drums were placed in outside storage from 1958 until 1968. Initial leakage was detected in 1964. The change in the distribution of this contamination on the plant property during a period of one year suggested that a gradual southeastward movement may have taken place.

3. The wind rose averaged over a 17-year interval at the Rocky Flats plant is given in Figure 1 . West winds occur almost $25 \%$ of the time; over $50 \%$ of the winds have a westerly component. The strongest gusts and the directions of the most frequent strong gusts (speeds greater than $40 \mathrm{mph}$ ) are from the west. The resultant wind vector (derived from the wind rose frequencies and mean speeds) points almost exactly eastward. 
FIGURE I

AVERAGE WIND ROSE AT ROCKY FLATS PLANT

$1953-1970$

ARROWS POINT TOWARD THE DIRECTION THE WIND IS

BLOWING; NUMBERS AT END OF ARROWS REPRESENT

VELOCITY IN MPH. LENGTH OF ARROWS AND CONCENTRIC

CIRCLES REFLECT FREQUENCY OF WIND DIRECTION.

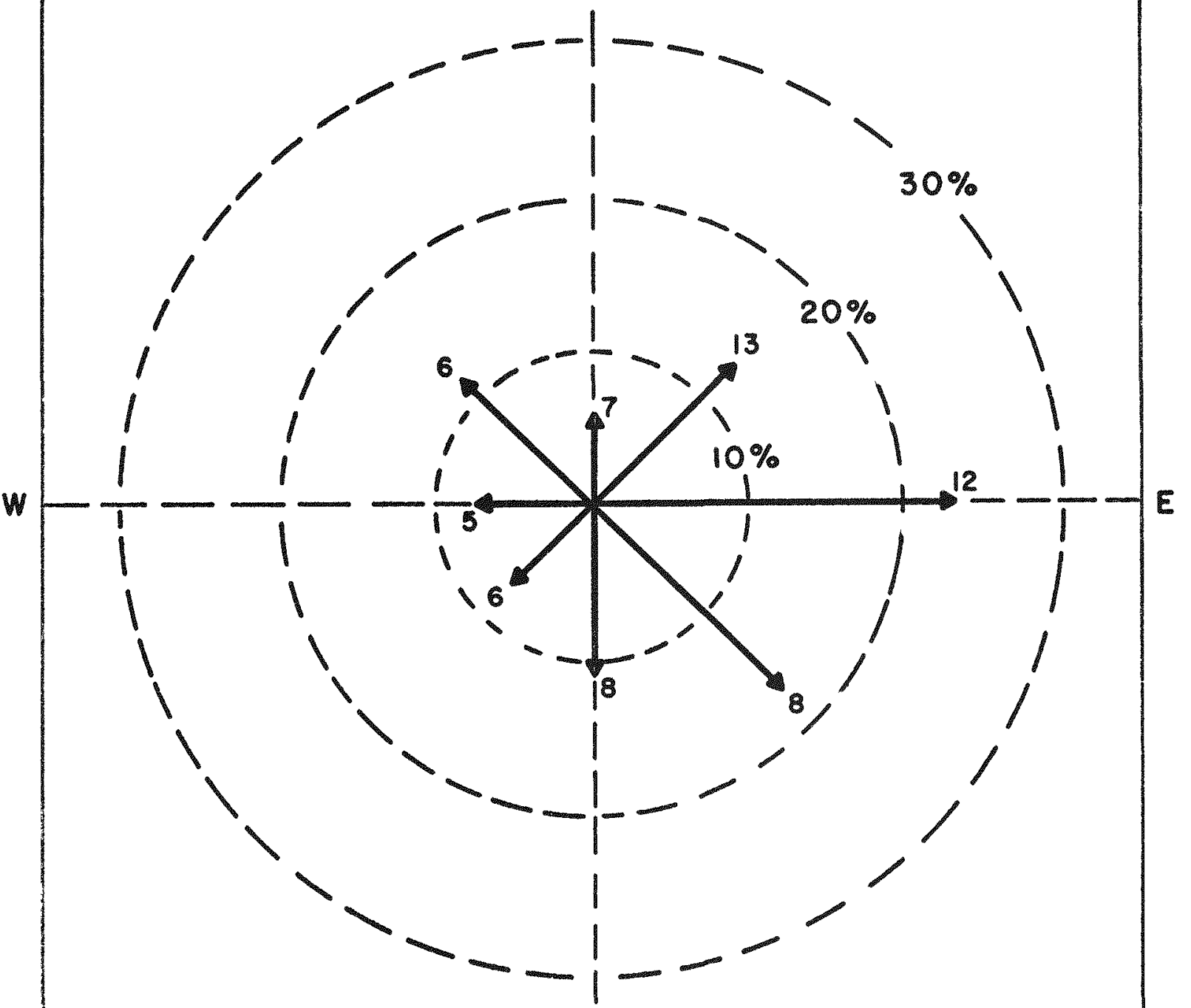

CALM 2\%

VARIABLE $5 \%$ 
The Denver wind rose shows that southerly to southwesterly winds are most frequent. Air flowing eastward from Rocky Flats should merge with the southerly air flow across Denver and be carried north-north eastward. The South Platte River Valley, about 20 miles east of Rocky Flats, is the logical terrain feature along which this transition from westerly flow should approach completion.

The wind direction on 5/11/69, the day of the last serious fire. was mostly from the north - northeast at speeds from 2 - $10 \mathrm{mph}$. Figure 2 gives mean hourly winds during that fire. The wind directions during the $9 / 11 / 57$ fire are shown in Fig. $3^{(4)}$.

4. Strong gusty winds frequently occur in the lee of the mountains at Rocky Flats; several days each year wind gusts exceed 70 to $80 \mathrm{mph}$. Consequently. wind erosion has removed much of the fine soil and alluvium leaving mostly rock and sand particles at the ground surface. Two creeks, Walnut and Woman Creeks, pass to the north and south of the plant in an easterly direction. These creeks begin to flow through significantly deep gullies (several hundred yards wide) as they flow by the eastern limits of the plant. The soil in the gullies which was wind eroded from the flats is finer and deeper, and is more likely to become a trap for windborne particles of plutonium. 
N

FIGURE 2

AVERAGE HOURLY WINDS DURING FIRE

OF MAY 11,1969

ARROWS POINT TOWARD THE DIRECTION THE AVERAGE

MOURLY WINDS WERE BLOWING. THE LENGTH OF THE

ARROWS AND THE CONCENTRIC CIRCLES REFLECT THE

WIND VELOCITY IN MPH.

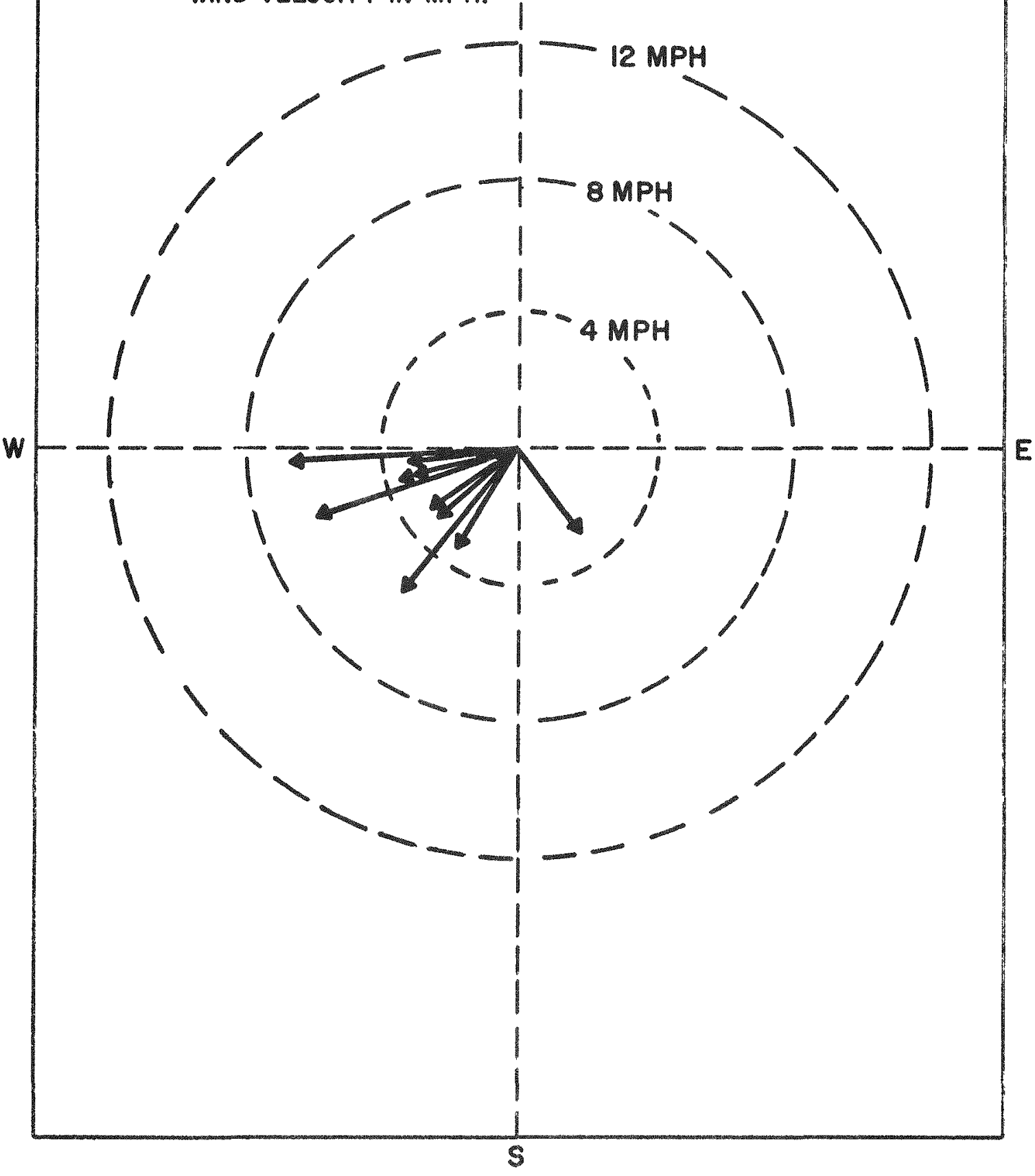




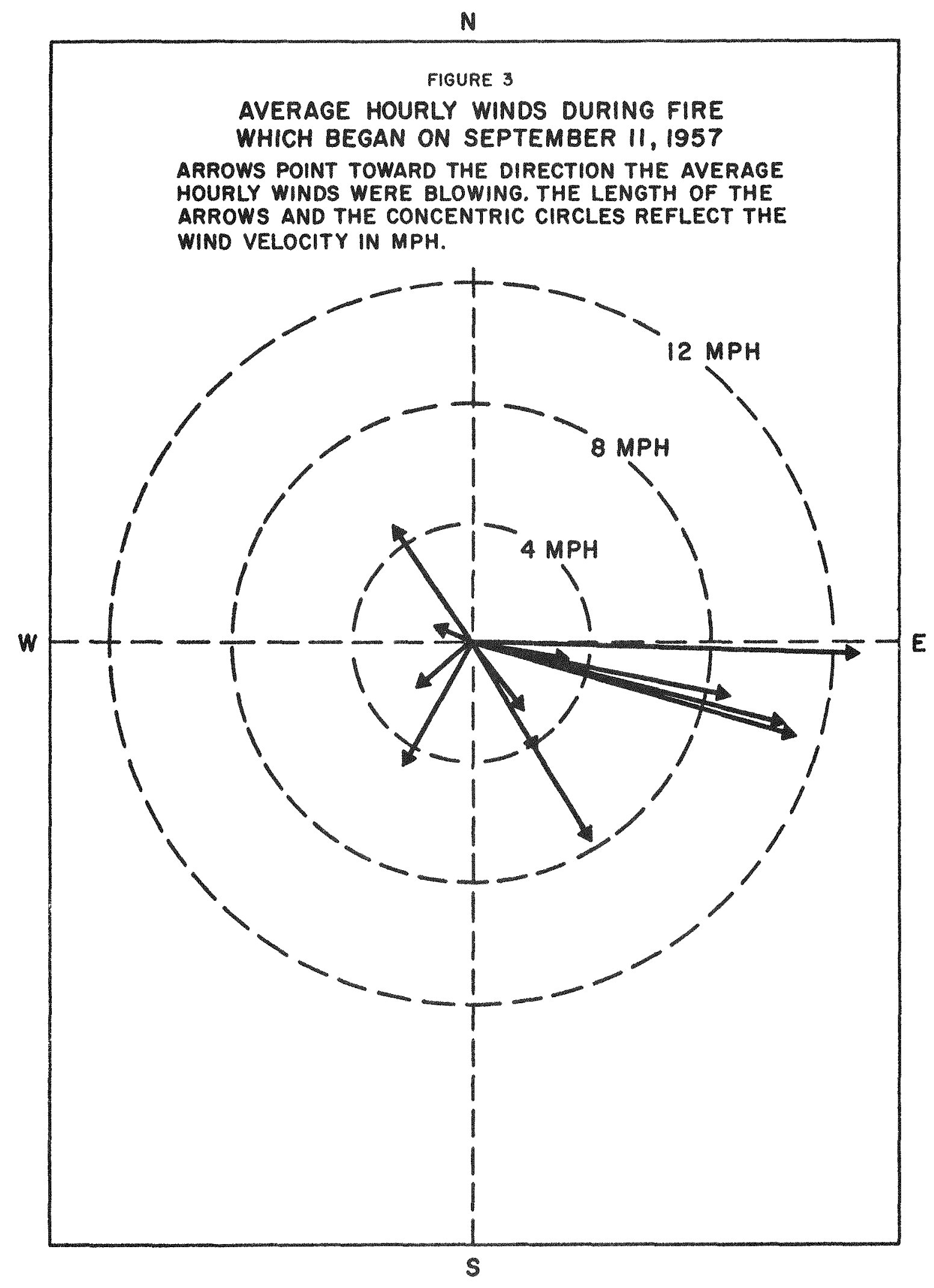




\section{Sampling site Location}

The week of February 9, 1970 was set aside for the collection of the soil samples. Based upon the pre-operational survey, emphasis was given to site location in the downwind direction from the plant. If the results of this limited one week sampling revealed serious deficiencies. the intent was to collect additional samples later to satisfy the need. The selected sampling sites and their description are given in Table 1 and plotted in Figure 4.

\section{SOIL SAMPLING}

The sampling techniques used in the Rocky Flats area were primarily dependent upon the rockiness of the soil. In those areas where rocks did not pose a problem, we used the core sampling method ${ }^{(5)}$. In the immediate vicinity of the Rocky flats plant, core sampling was not possible. Here it was necessary to cut out a one square foot area sample to the required depth. We tried to select sites for sampling that had been undisturbed since the plant started operations in 1953. The sites were vegetated and in large flat open areas where it could reasonably be assumed that deposited material would not have been removed by water erosion. We avoided sites where debris might have accumulated such as in depressions, at the foot of slopes, or in flooded areas. Our objective was to take samples that would 


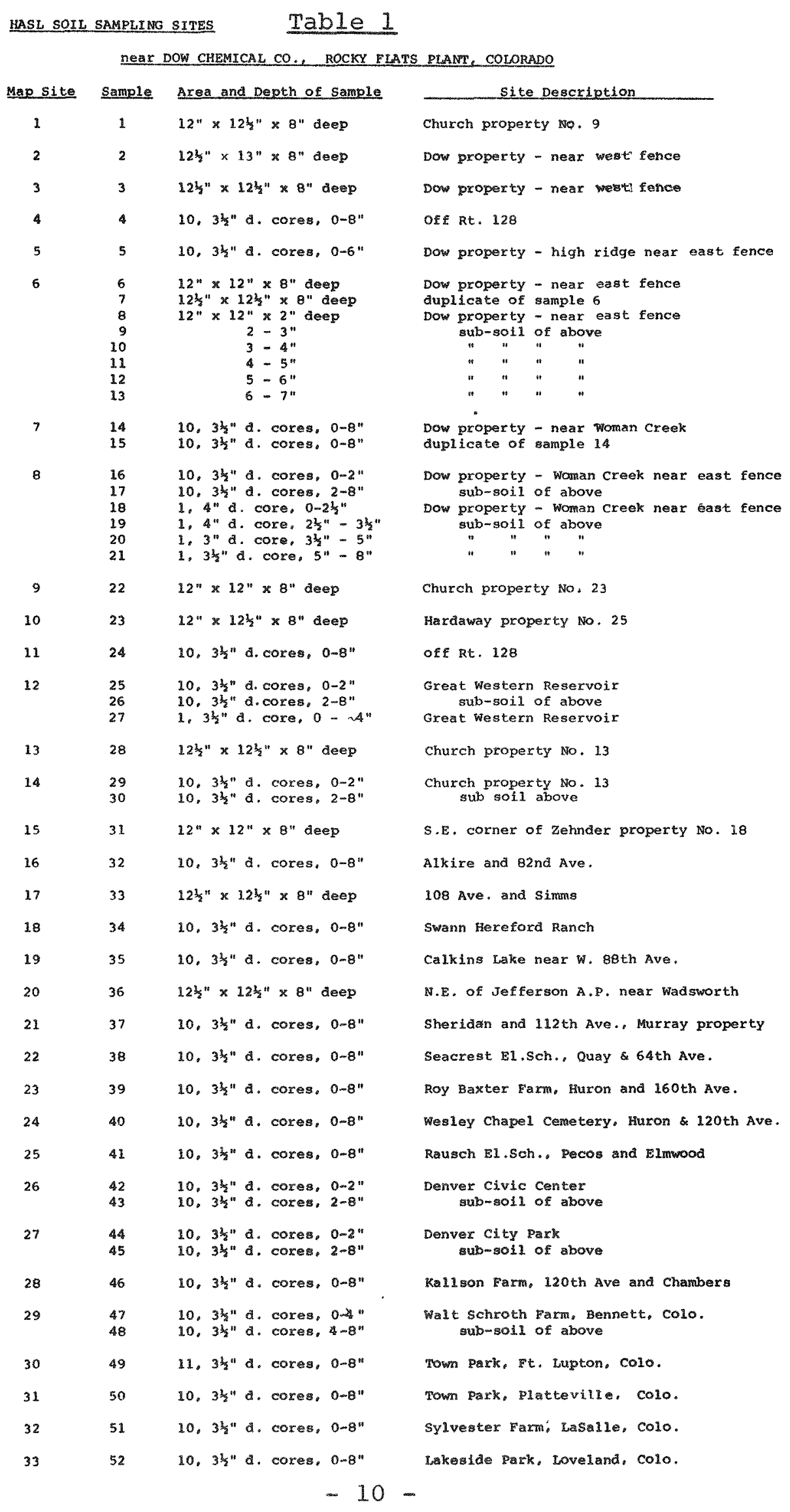


Figure 4

HASL SOIL SAMPLING SITES NEAR DOW CHEMICAL CO.,ROCKY FLATS PLANT

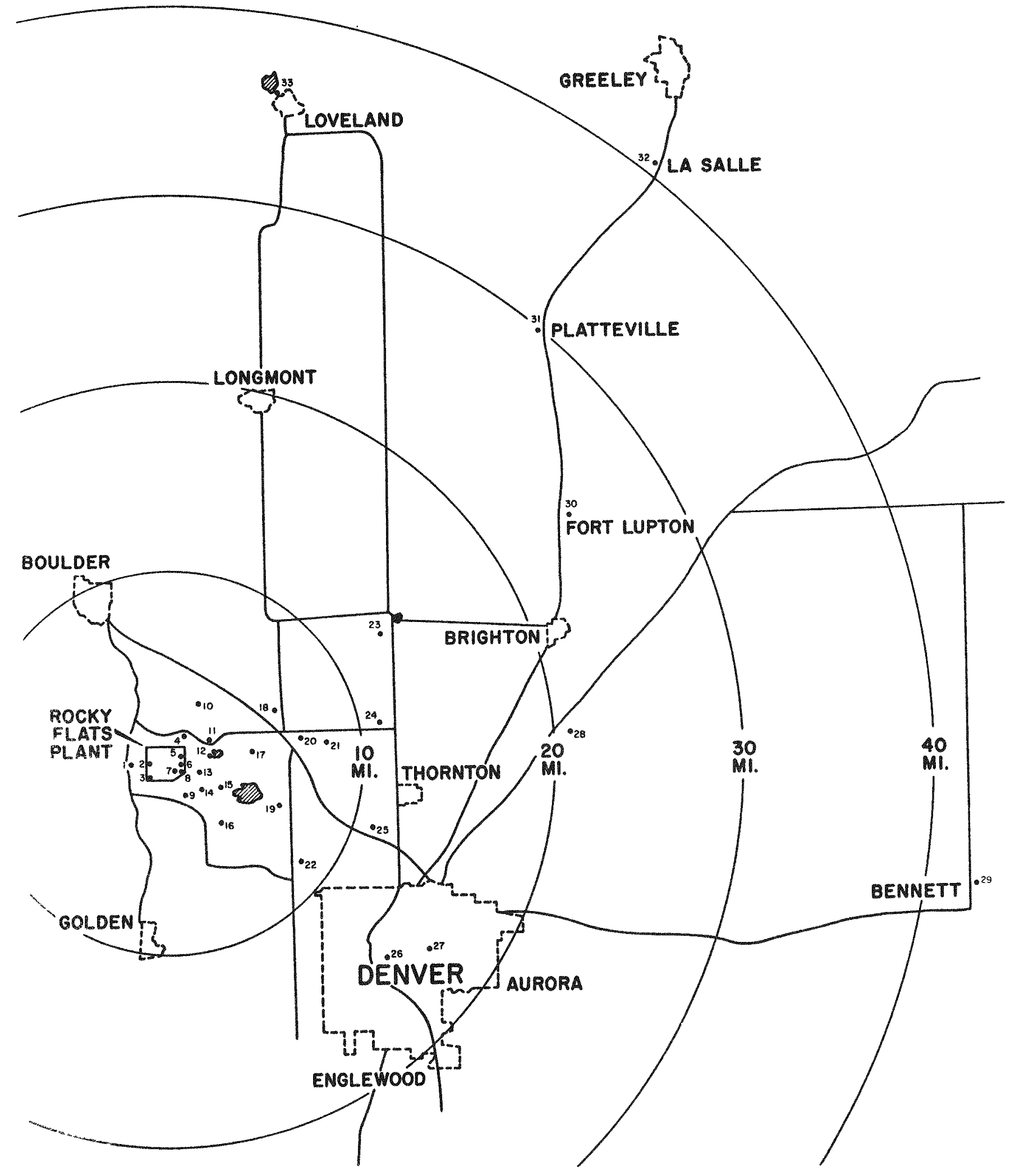


measure the total amount of plutonium that had fallen out. At the time, we arbitrarily decided to sample from the surface down to 20 centimeters, expecting that at this depth we would include all the plutonium. We shall briefly describe the sampling techniques used.

In those areas where core sampling was possible, we first laid out a straight line transect about 5 meters long. With about $30 \mathrm{~cm}$ (one foot) spacings in between cores, we cut out ten $8.9 \mathrm{~cm}$ ( $3.5 \mathrm{in.}$ ) diameter plugs from the surface to $5 \mathrm{~cm}$, including the vegetation and root mat. In this way we sampled an area of $622 \mathrm{~cm}^{2}\left(0.67 \mathrm{ft}^{2}\right)$. Next we removed the soil from 5 to $20 \mathrm{~cm}$ with an auger which bores an $8.9 \mathrm{~cm}$ diameter hole. At some sites, we separated the $0-5 \mathrm{~cm}$ and $5-20 \mathrm{~cm}$ samples. In most cases, however, the two fractions were combined. Further sampling details and descriptions of the tools are given elsewhere ${ }^{(5)}$.

At map site No. 8, we sampled a one hole depth profile by mechanically drilling with hole saws to a depth of $13 \mathrm{~cm}$. Sampling from 13 to $20 \mathrm{~cm}$ was done with the hand auger.

At those sites where there was a preponderance of rocks in the soil, the preferred method of core sampling could not be done. Instead we placed a 930 square centimeter (one square foot) metal 
template on top of the spot selected for sampling and cut out the sample with chisels and scoops. The rocks were included with the sample.

At map site No. 6, we took samples of soil at various depths down to $20 \mathrm{~cm}$. This was a very rocky area so that we had to use the one square foot template and chisel out the samples as carefully as possible. The first $5 \mathrm{~cm}$ were relatively easy to sample but as we went down in depth it was necessary to taper toward the center of the $930 \mathrm{~cm}^{2}$ area to avoid contaminating with soil from the upper levels. Consequently we could not get an accurate area measurement below $5 \mathrm{~cm}$. To convert from the measured concentrations (dpm per gram) to activity per unit area we assumed a soil density of 1.2 grams per $\mathrm{cm}^{3}$ down to $15 \mathrm{~cm}$ and 2.4 grams per $\mathrm{cm}^{3}$ from 15 to $18 \mathrm{~cm}$. These density values were obtained as averages of a considerable body of data accumulated at HASL over a 15 year period. As we sampled the depth profile at this site, we removed and discarded the rocks. Ten of the Rocky Flats samples required the removal of the larger rocks. We assumed that an insignificant amount of plutonium would be in the rock fraction and consequently based the calculated activity per unit area on the weight of the soil fraction. To be 
sure this was proper, we analyzed the separated rock fraction of the soil containing the highest concentration of plutonium. We found only 0.2 percent of the total plutonium associated with the separated rocks and therefore neglected the rock fraction in the remaining samples.

\section{RADIOCHEMICAL ANALXSIS}

\section{Sample Preparation}

When the soil samples arrived at HASL, they were spread out on plastic sheets and allowed to air dry for several days. During the drying process, we broke up soil aggregates and pulled apart the top soil plugs consisting of vegetation and root mat. We cut up the vegetation so that it could be distributed homogeneously throughout the sample. When the sample was completely dry it was weighed in its entirety. Then, when necessary, any rocks were removed and weighed separately.

The sample was then crushed and transferred to a blendex. After mixing, we spread the sample out on a piece of plastic, marked off quarters, and took scoop fulls from each quartex in a consecutive manner until about a kilogram had been collected. This sub-sample was then pulverized in a rotary hammer mill and transferred to a polyethylene bottle. 
One hundred gram aliquots of the pulverized material were aliquoted at various times for submission to the analytical laboratory. This soil sample preparation procedure and equipment used for crushing, blending, and pulverizing are described elsewhere

\section{Radiochemical procedure}

The radiochemical procedure for plutonium in soil was developed by Norton Chu at the Health and Safety Laboratory. It involves leaching a 100 gram aliquot of soil with hydrochlorlc and nitric acids. We show below that this method effectively removes all the plutonium. Plutonium is isolated by anion exchange (nitrate form) and electrodeposited on a platinum disc. The plutonium isotopes are resolved. by alpha spectrometry and yielded with Pu-236. This procedure is described in detail elsewhere (5).

Most of the analyses of the Rocky flats soils were done by two contractor laboratories: Teledyne Isotopes of Palo Alto. California (designated here as IPA) and Trapelo Division west of Richmond. California (TLW)

Complete dissolution of a sample for radiochemical analysis is the classical and most dependable method of analysis. However, in the case of soil, it is also most difficult, tedious, and time consurning. The HASI leach method was developed to eliminate the need 
for complete dissolution but to provide accurate, dependable results. To show that the leach method fulfilled its objectives. many samples were analyzed by both leaching and complete dissolution and gave comparable results.

Three different samples from Rocky Flats were selected as representing widely different soil types. Duplicate aliquots of each were analyzed for Pu-239 by the leach and fusion methods. The fusion method affords complete dissolution of the sample by decomposing it in molten sodium carbonate. Table 2 gives the results of these analyses and shows that the mean percent deviation between the methods was $13 \%$ with no obvious bias.

Other soils were similarly analyzed and the results are also reported in Table 2 . A second method of complete dissolution was used for some of these samples, and is indicated as HF dissolution in the table. This technique affects complete dissolution by prolonged digestion of the sample with hudrofluoric and perchloric acids. The mean percent deviation between methods for these soils is $12 \%$ which is not statistically different from the pattern in the Rocky Flats soils. These data convincingly demonstrate that the leach procedure permits an accurate assessment of the plutonium content in many, if 
Table 2

\section{COMPLETE DISSOLUTION VERSUS LEACHING}

Rocky Flats Soils

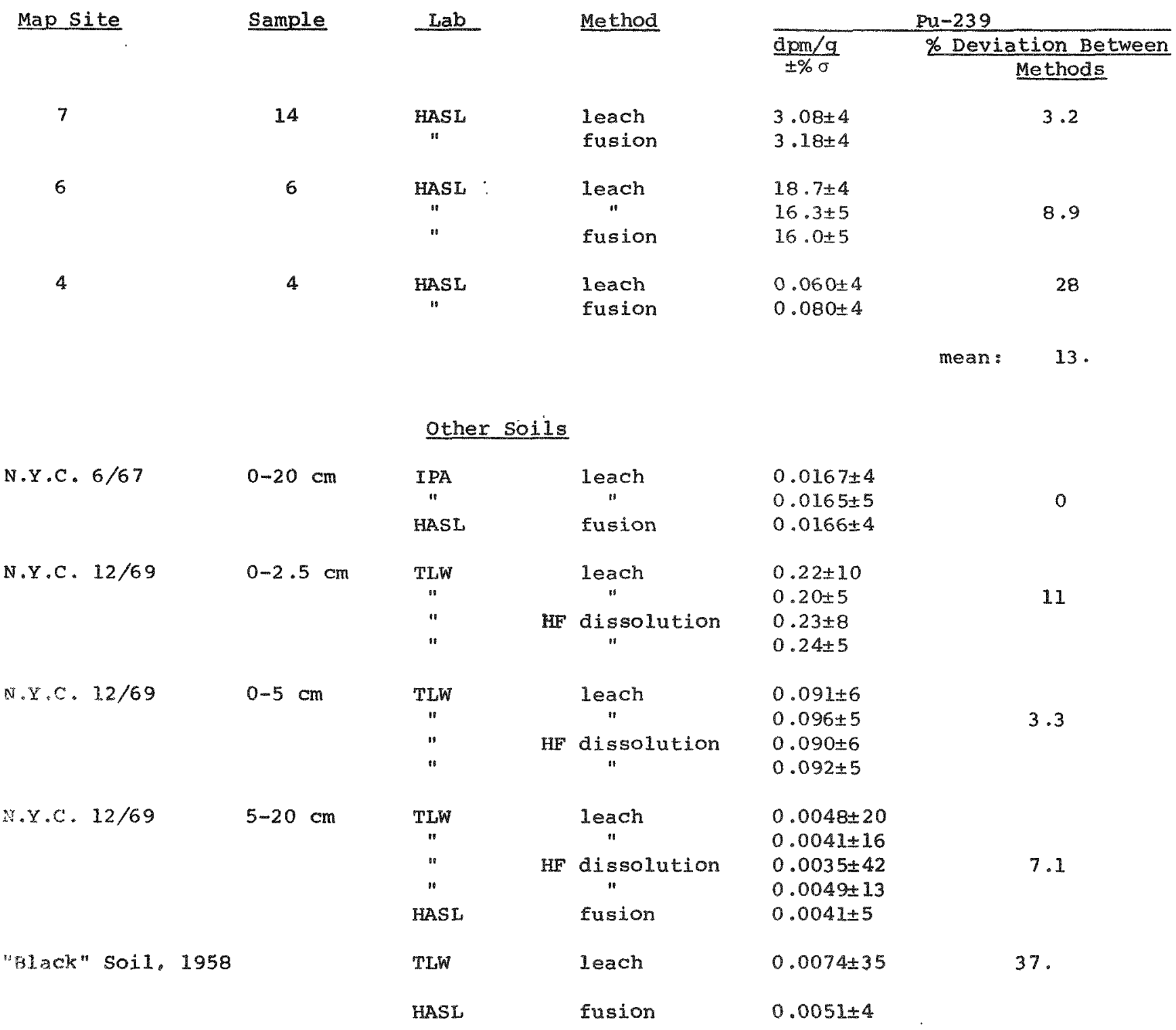

mean: 12 . 
not all, soils and cextainly in the soils encountered in the Rocky Flats area.

The deviations between methods reported in Table 2 include the errox terms attendant to aliquoting and analytical precision. If the sample is not homogenized, deviations between aliquots will be high. By minimizing the error due to analytical precision, the data in Table(2) suggests that the error due to aliquoting is $\pm 13 \%$ or less.

\section{RES U L T S}

The Pu-238 and Pu-239 analyses of all the Rocky Flats samples plus additional reference samples are given in Tables $A$ and $B$ of the Appendix. Complete information regarding the collection area, the depth and weight of sample or fraction thereof, the analytical laboratory, and $\mathrm{Pu}-238 / \mathrm{Pu}-239$ ratios are also reported. The $\mathrm{mCi} / \mathrm{km}^{2}$ of Pu-239 and Pu-238 integrated from $0-20 \mathrm{~cm}$ at each map site was calculated from Table $\mathrm{A}$ and is summarized in Table 3 along with the integrated Pu-238/Pu-239 ratio. When duplicate analyses were reported, the average of the duplicates were used in calculating the map site value unless otherwise specified in Table A. The deposition contours derived from Table 3 are plotted in Figure 5. 
Since a number of earlier reports gave their data only in units of dpm/g soil, these values are also shown in Table $A$. These units are not at all useful for our study, and are difficult to compare without specifying depth of sampling and sample pretreatment. The results of the depth profile studies are summarized in Table 4 as percent of the integrated activity down to $20 \mathrm{~cm}$ found in each incremental depth sampled. Profiles of fallout plutonium in New York City and Waynesville, Ohio are included for comparison.

*Footnote: From Table $A$ it can be seen that at map site No. 8 the $13-20 \mathrm{~cm}$ increment contained more plutonium than the preceding increment. In evaluating this depth profile in Table 4 we summed the $9-13 \mathrm{~cm}$ and the $13-20 \mathrm{~cm}$ values and reported the total activity per unit area from $9-20 \mathrm{~cm}$. Similarly at map site No. 6 we combined the $13-15 \mathrm{~cm}$ and $15-18 \mathrm{~cm}$ values for presentation in Table 4. 
Table 3

TOTAL PLUTONIUM DEPOSITED AT SOIL SAMPLTNG SITES

IN THE ROCKY FIATS AREA

Map Site

2

3

4

5

6

7

8

9

10

11

12

13

14

15

16

17

18

19

20

21

22

23

24

25

26

27

28

29

30

31

32

33
Pu-239

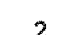

2.4

3.1

4.2

11.

15

1950 .

480 .

630.

2.6

2.2

5.4

47.

50.

17

18.

19

14.

2.0

8.0

2.6

2.7

2.2

3.0

2.6

2.4

2.3

2.0

2.5

2.0

2.8

2.1

2.7

1. 8
0.07

0.06

0.12

0.23

0.36

37.7

8.9

12.5

0.07

0.63

0.25

1.2

0.94

0.39

0.32

0.41

0.23

0.06

0.20

0.13

0.06

0.13

0.07

0.06

0.07

0.16

0.05

0.20

0.15

0.15

0.06

0.22

0.06

$$
-20-
$$

$\mathrm{Pu}^{238}$

$\mathrm{Pu}^{239}$

0.029

0.019

0.028

0.021

0.024

0.019

0.018

0.020

0.027

0.29

0.046

0.026

0.019

0.023

0.018

0.022

0.016

0.030

0.025

0.050

0.022

0.059

0.023

0.023

0.029

0.070

0.025

0.080

0.075

0.054

0.028

0.081

0.033 


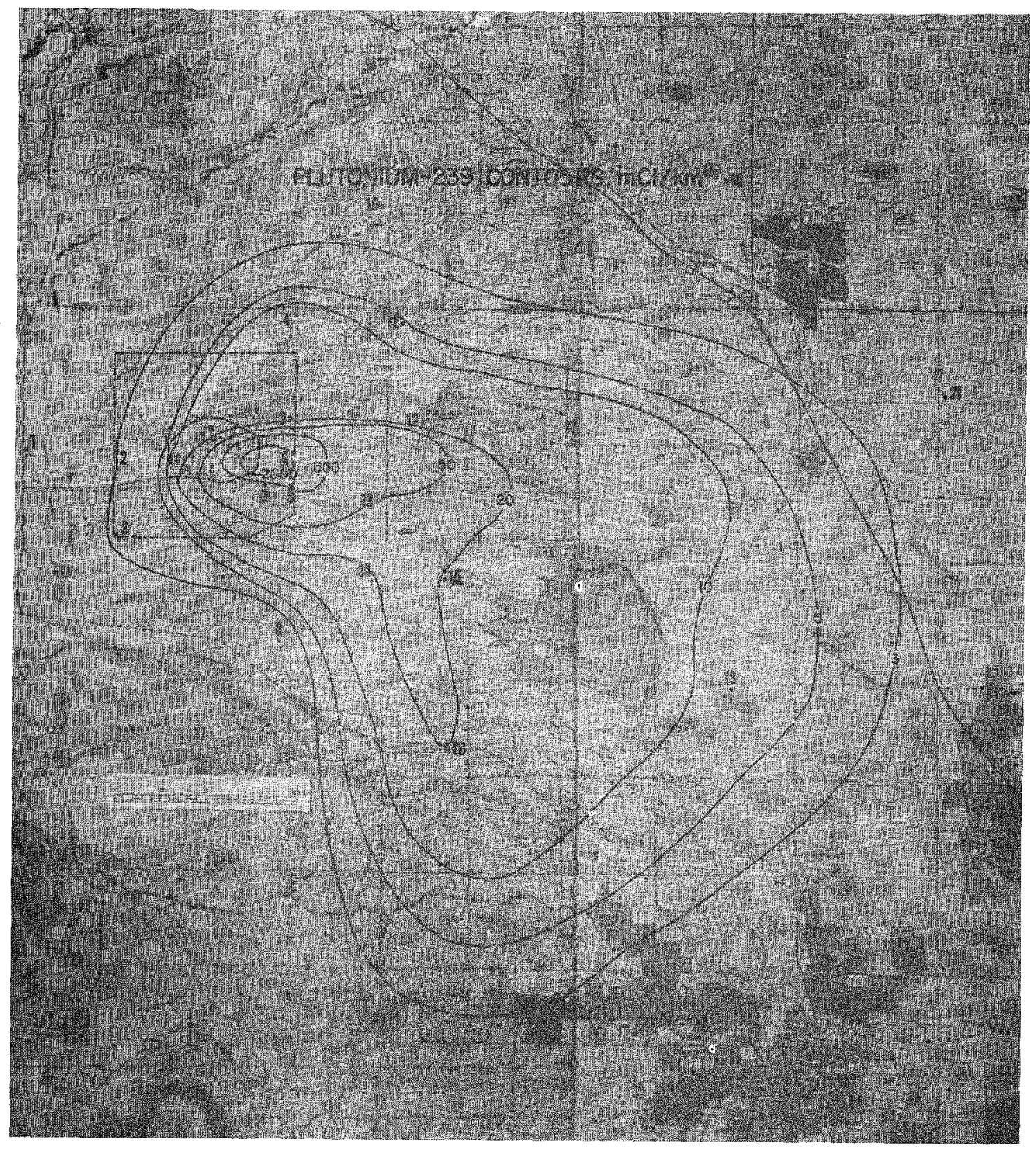

Figure 5:

PLUTONIUM-239 CONTOURS AROUND ROCKY FLATS

contour values in mCi per $\mathrm{km}^{2}$ (1ight figures)

Numbered sampling sites (bolder figures)

AEC property boundary -.......

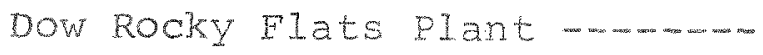


Table 4

DEPTH DISTRIBUTION OF PLUTONIUM Rocky Flats soils

\begin{tabular}{|c|c|c|}
\hline Map site & $\begin{array}{l}\text { depth } \\
(\mathrm{cm})\end{array}$ & $\begin{array}{l}\% \text { of } \\
\text { total Pu239 } \\
\end{array}$ \\
\hline \multirow[t]{5}{*}{6} & $0-5$ & 68 \\
\hline & $5-8$ & 24 \\
\hline & $8-10$ & 6 \\
\hline & $10-13$ & $I$ \\
\hline & $13-18$ & $<1$ \\
\hline \multirow[t]{3}{*}{8} & $0-6$ & 66 \\
\hline & $6-9$ & 21 \\
\hline & $9-20$ & 13 \\
\hline \multirow[t]{2}{*}{8} & $0-5$ & 67 \\
\hline & $5-20$ & 33 \\
\hline \multirow[t]{2}{*}{12} & $0-5$ & 91 \\
\hline & $5-20$ & 9 \\
\hline \multirow[t]{2}{*}{14} & $0-5$ & 61 \\
\hline & $5-20$ & 39 \\
\hline \multirow[t]{2}{*}{26} & $0-5$ & 39 \\
\hline & $5-20$ & 61 \\
\hline \multirow[t]{2}{*}{27} & $0-5$ & 45 \\
\hline & $5-20$ & 55 \\
\hline \multirow[t]{2}{*}{29} & $0-10$ & 92 \\
\hline & $10-20$ & 8 \\
\hline
\end{tabular}

\section{Other soils}

\begin{tabular}{|c|c|c|c|}
\hline Site & $\begin{array}{l}\text { Sampling } \\
\text { date }\end{array}$ & & \\
\hline New York City & Dec. 1969 & $0-2 \frac{1}{2}$ & 66 \\
\hline & & $\begin{array}{l}0-5 \\
5-20\end{array}$ & $\begin{array}{l}81 \\
19\end{array}$ \\
\hline
\end{tabular}

Waynesville, Ohio Apr. 1970

$\begin{array}{ll}0-6 & 47 \\ 6-20 & 53\end{array}$




\section{QUALITY CONTROL}

HASL carries on an elaborate and extensive quality control program, both internally and with its contractors, to assure the validity of reported analyses. Since this particular study differs from our fallout programs, the quality control procedures and results are reported here in detail.

To monitor the quality of the analytical results, blind control samples were admixed with the normal schedule of routine samples. These controls included blank or low level $\mathrm{Pu}-239$ samples, duplicate aliquots of prepared samples, and several reference samples.

\section{Blank and Low level Samples}

Two low level samples were used. One was a pre-bomb soil. that is a soil collected prior to 1945 which is the birth year of nuclear weaponry. A second was a soil sample retrieved from the town of Woodcliff Lake. New Jersey in March 1970 at a depth below 90 $\mathrm{cm}$ which was processed along with the other samples. The results of the analyses of these two samples are given in Table 5 .

In general, the results in Table 5 show no detectable plutonium activity in the pre-bomb sample and a surprising value of about $0.005 \mathrm{dpm}$ per gram Pu-239 for the Woodcliff Lake sample. Either a 
Table 5

PLUTONIUM IN BLANK AND LOW LEVEL SAMPLES

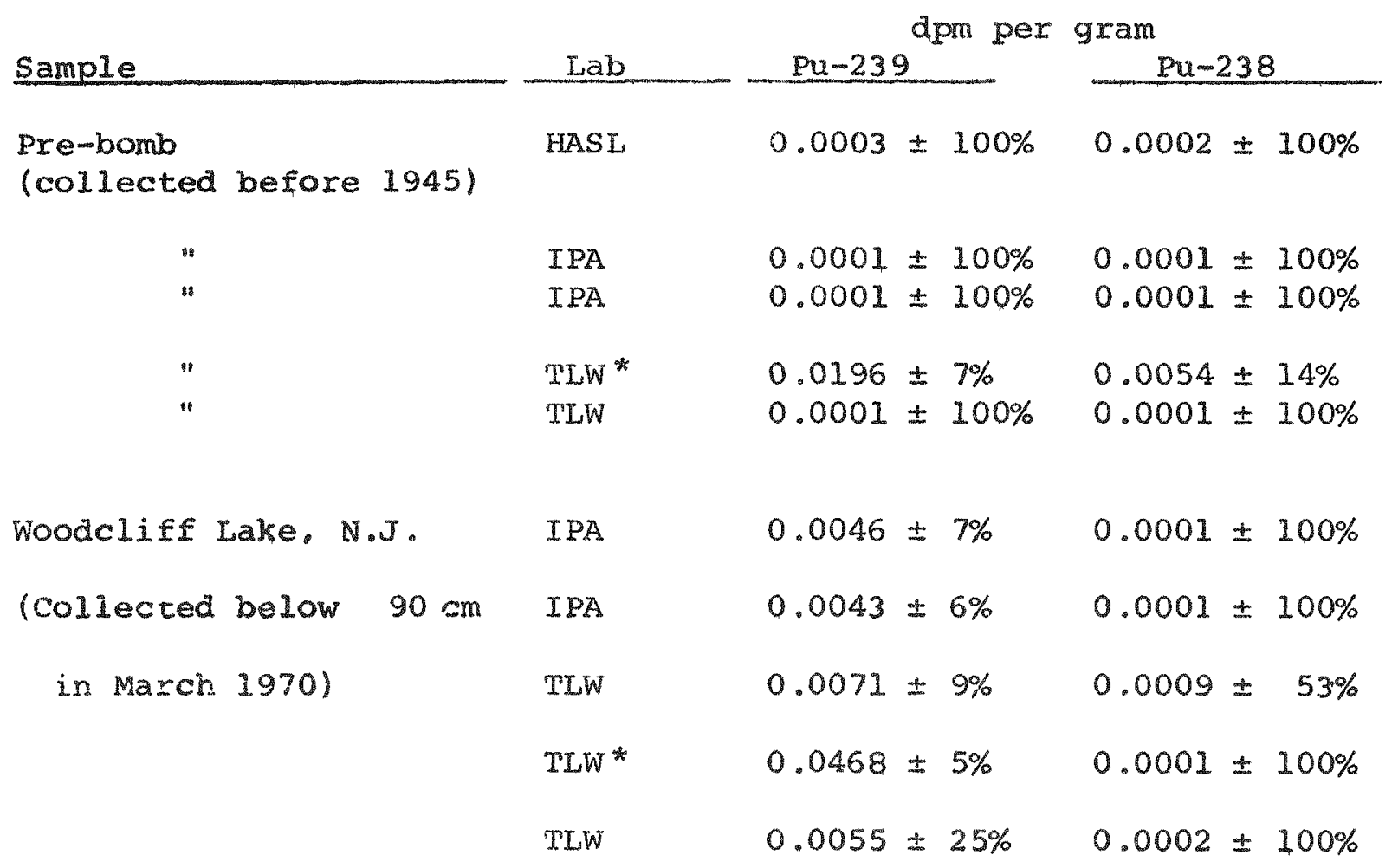

* Suspect value 
small amount of pu-239 penetrated to that depth or more reasonably the sample was slightly contaminated during collection or subsequent pre-analyses treatment. However, in one of the replicate analyses of each of these samples. Trapelo appears to have introduced from 2 to $4 \mathrm{dpm}$ of $\mathrm{Pu}-239$ contamination (100 gram aliquots were analyzed). This can represent a major portion of the total activity found in samples remote from the Rocky Flats plant; although the data in Table 5 also suggest that this contamination at Trapelo is not consistent. Examination of Table 5 and Tables $A$ and $B$ in the Appendix indicates that, on balance, contamination by laboratory handing and analyses was not measurable or was relatively unimportant to the outcome of this study.

\section{Analytical Precision}

The percent deviation between aliquots of a prepared sample. which represents the difference between aliquots divided by the mean, was calculated for each set of duplicates in Tables A and B. The data were subdivided into the internal replication at IPA. TLW, and.HASI and also into the replication between these laboratories. Then the mean percent deviation between aliquots for each subgroup was computed and is reported in Table 6 . It should be noted that 
the results of several samples reported by TLW were suspect, and duplicate aliquots of these samples were subsequently submitted to IPA for verification. These sets of duplicates were included in the compilation of Table 6 and reflect a slight bias against the random selection of duplicate sets.

Table 6 indicates that the precision of Pu-239 analysis both internally and between IPA and HASL ranged up to $\pm 28 \%$ and averaged below $\pm 20 \%$. The internal precision at TLW and the precision between TLW and the other laboratories was 3 times higher. These uncertainties reflect not only the precision of analysis but also the representivity of aliquoting the prepared sample. For example, Table 2 suggests that aliquoting Rocky Flats soils gives an average uncertainty of less than 13\%. Each of the results of the Rocky Flats soil analyses were examined in the light of expected results based upon location and comparison to neighboring samples. Reanalyses were performed when deemed necessary, and data were accepted depending upon their reasonableness and the laboratory conducting the analysis. Therefore, the overall analytical precision was about $\pm 20 \%$.

The level of Pu-238 in many of the samples was so low as to incur large counting errors. If either aliquot had a counting error 
Table 6

MEAN PERCENT DEVIATION BETWEEN ALIQUOTS

Pu-239

Laboratory

No. of Sets \% Deviation

IPA

5

14

TLW

8

73

HASL

1

14

IPA/HASL

3

28

TLW/HASL

1

56

TLW/ IPA

9

58 
greater than $\pm 30 \%$, that duplicate set was omitted from further consideration. With that limitation, the mean percent deviation between aliquots for Pu-238 analyses was very similar to the behavior of $\mathrm{Pu}-239$.

\section{Analytical Accuracy}

The accuracy of the Pu-239 analyses is difficult to establish because of the lack of a standard soil sample. However, several reference samples were analyzed in which the plutonium levels can be approximated from their Sr-90 content. Table 7 identifies these samples giving the Sr-90 measurements, the expected Pu-239 values based upon a Pu-239/Sr-90 ratio of 0.02 (6), and the reported Pu-239 measurements. The "red" and "black" soils which were collected in 1958 at Raleigh, North Carolina and McHenry County. Illinois, respectively, were prepared as reference soil samples and were analyzed many times for $\$ x-90$ content. The initial pu-239 analyses of the "red" and "black" soils by TLW reflected the laboratory contamination discussed earlier. The re-analyses gave values which are about twice the expected values but in agreement with HASL's estimate of the "black" soil using the fusion treatment. The measured Pu-239 in the Derby. Colorado (1965) and New York City (1967) 
Table 7

ANALYSES OF REFERENCE SAMPLES

$\mathrm{dpm} / \mathrm{g} \pm$ stnd Dev. \%

\section{Sample}

"Red Soil"

"Black Soil"

Derby, Colorado

New York City

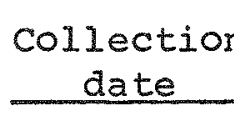

1958

1958

1965

1967

\begin{tabular}{|c|c|c|c|c|}
\hline$s r-90$ & $\begin{array}{l}\text { Expected (I) } \\
\text { Pu-239 }\end{array}$ & $\begin{array}{l}\text { Measured } \\
\text { TLW }\end{array}$ & $\begin{array}{l}\text { Pu-239 (dpm per } \\
\text { IPA }\end{array}$ & $\begin{array}{r}\text { gram) } \\
\text { HASI } \\
\end{array}$ \\
\hline $0.14 \pm 6$ & 0.0028 & $\begin{array}{l}0.0567 \pm 8^{(3)} \\
0.0061 \pm 14\end{array}$ & & \\
\hline $0.18 \pm 4$ & 0.0036 & $\begin{array}{l}0.0399 \pm 9^{(3)} \\
0.0074 \pm 35\end{array}$ & & $0.0051 \pm 4^{(2)}$ \\
\hline $0.43 \pm 7$ & 0.0086 & $0.0110 \pm 7$ & $0.0112 \pm 4$ & \\
\hline $0.66 \pm 3$ & 0.0132 & & $\begin{array}{l}0.0167 \pm 4 \\
0.0165 \pm 5\end{array}$ & \\
\hline
\end{tabular}

\footnotetext{
(1) Assuming Pu-239/5r-90 $=0.02$

(2) Analysis performed by fusion of sample

(3) Suspect value
} 
samples are also higher than the expected values but by less than a factor of two. While these results cannot quantify the accuracy of analysis, they do demonstrate the acceptability of the method.

The laboratories performing these analyses were in good calibration with standard solutions of Pu-238 and Pu-239 made available by HASL. From these quality control studies it appears that the precision of replicate aliquoting and analysis is the determining factor in the uncertainty of the analytical results, and that the overall reliability of the analyses is within $\pm 25 \%$.

\section{Representivity of Soil Sampling}

To demonstrate that the sample collected was representative of the soil contamination at the sampling site, duplicate samples were collected by each of the two methods of sampling, and the results of these analyses are shown in Table 8 . One sample of each duplicate sample was analyzed in replicate while the second duplicate was analyzed only once.

The template sampling method at map site 6 reflected a $\pm 31 \%$ deviation between duplicate samples for Pu-239 while the coring method at map site 7 showed only a $\pm 11 \%$ deviation. The Pu-238 results were similar because the $\mathrm{Pu}-238 / \mathrm{Pu}-239$ ratio for all samples 
Table 8

DUPIICATE SOIL SAMPLING IN THE ROCKY FLATS AREA

\begin{tabular}{|c|c|c|c|c|c|c|}
\hline Map Site & $\begin{array}{l}\text { depth } \\
\text { (cm) }\end{array}$ & $\begin{array}{l}\text { Sampling } \\
\text { method }\end{array}$ & $\begin{array}{l}\text { No. of } \\
\text { analyses }\end{array}$ & $\begin{array}{r}m C i \\
\mathrm{Pu}-239 \\
\end{array}$ & $\begin{array}{l}\mathrm{km}^{2} \\
\mathrm{pu}-238 \\
\end{array}$ & $\frac{\mathrm{Pu}^{238}}{\mathrm{Pu}^{239}}$ \\
\hline \multirow[t]{2}{*}{6} & $0-20$ & Template & 4 & 2050 & 40.3 & 0.020 \\
\hline & & & 1 & 1500 & 27.4 & 0.018 \\
\hline \multirow[t]{2}{*}{7} & $0-20$ & cores & 3 & 490 & 9.4 & 0.019 \\
\hline & & & 1 & 437 & 7.5 & .0 .017 \\
\hline
\end{tabular}


was remarkably constant. This precision is not unlike the precision of replicate analyses of identical samples. We conclude that the representivity of soil sampling is good and that the uncertainty of the final data is due largely to the imprecision of aliquoting and analysis.

\section{DISCUSSION}

Distribution with depth

Significant quantities of $\mathrm{Pu}-239$ are below the top $5 \mathrm{~cm}$ of soil and vegetation. Table 4 shows that between 9 and 61 percent of the Pu-239 from the surface to $20 \mathrm{~cm}$ in depth is below $5 \mathrm{~cm}$, depending upon the particular type of soil. At map sites nos. 6 and 8 we sampled three or more increments to see how the plutonium was distributed with depth. Although about $90 \%$ was in the top $9 \mathrm{~cm}$ we were able to measure Pu-239 as far down as $13 \mathrm{~cm}$. We would conclude. however, that at these sites less than $1 \%$ is below this depth. At five other sites we separated the $0-5 \mathrm{~cm}$ and $5-20 \mathrm{~cm}$ fractions and found widely varying percentages of the total Pu-239 measured, below $5 \mathrm{~cm}$. Undoubtedly the base exchange capacity and perhaps other characteristics of the soil are important factors in determining the extent to which deposited plutonium will penetrate below the surface. Sites Nos. 26 and 27 were in city parks where 
liming and fertilization may enhance the downward movement. Lacking better definition of the plutonium distribution with depth at these other sites we assumed that in sampling to $20 \mathrm{~cm}$ we removed essentially all of the plutonium that had fallen out.

\section{Inventory}

The areas within the various contours of Figure 5 were determined by planimetry, and the total Rocky Flats pu-239 burden in the soil bounded by the $3 \mathrm{mCi} / \mathrm{km}^{2}$ contour is estimated to be $4.5 \mathrm{Ci}$. One objective of this study was to determine the quantity of Pu-239 released to property not controlled by the AEC. The sampling plan reflected this objective by collecting few samples on the plant site. Consequently, our estimates of the Pu-239 within the plant area is poor and may be low. The Rocky Flats Pu-239 on public and private lands not controlled by the $\mathrm{AEC}$ and within the $3 \mathrm{mCi} / \mathrm{km}^{2}$ contour is estimated to be $2.6 \mathrm{Ci}$.

There is no question that Rocky Flats plutonium extended beyond the $3 \mathrm{mCi} / \mathrm{km}^{2}$ contour, but the extent of this low level contamination is difficult to define. Table B shows that the fallout Pu-239 in 1965 at Derby, Colorado which is only 17 miles east of Rocky Flats was $1.5 \mathrm{mCi} / \mathrm{km}^{2}$. Additional nuclear weapons fallout from 1965 to 1970 would add little Pu-239 to this value. The observed values of 
2.0 and $1.8 \mathrm{mCi} / \mathrm{km}^{2}$ at map site Nos. 29 and 33 which were about 40 miles to the east and north of Rocky Flats, respectively, began to approach the expected fallout level of $1.5 \mathrm{mCi} / \mathrm{km}^{2}$. The intervening sites were somewhat higher and averaged about $2.5 \mathrm{mCi} / \mathrm{km}^{2}$. Taking the extreme and unlikely view that the entire area was contaminated with the difference $\left(1 \mathrm{mci} / \mathrm{km}^{2}\right)$ indicates that, as an upper limit, an additional $3.2 \mathrm{Ci}$ of $\mathrm{Pu}-239$ could have been released from the plant to the remote areas beyond the $3 \mathrm{mCi} / \mathrm{km}^{2}$ contour. The total released to non AEC controlled property would then increase to $5.8 \mathrm{Ci}$

This calculation of the remote contamination relies heavily upon the $1.5 \mathrm{mCi} / \mathrm{km}^{2}$ estimate of fallout plutonium in the area. The one measurement at Derby in 1965 is not sufficient for a sound argument. Sr-90 analyses of the remote site samples and other studies are in progress which might resolve the problem. However, a thorough solution may require additional sampling in the colorado area.

The Pu-238 measurements serve little useful purpose except to document the Pu-238/Pu-239 ratio of the Rocky Flats debris. The average ratio of this debris is about 0.020 . At the remote sites where there is a greater proportion of fallout plutonium. the ratio is higher reflecting the debris from the 1964 re-entry burn-up of the SNAP-9A generator. 


\section{Source of Contamination}

The distribution of Rocky Flats plutonium within the $3 \mathrm{mCi} / \mathrm{km}^{2}$ contour suggests that the leaking barrels were the source of the contamination. The average wind behavior over the 17 years of record (Figure 1) should distribute a chronic low-level stack effluent in a directorial pattern similar to the contamination contours shown in Figure 5. However, the downwind extent of the stack effluent would depend largely on the particle size of the plutonium. Even if only gravitational settling is considered for the $\mathrm{PuO}_{2}$ emitted from the 250 foot stack at the Dow plant, and if an average westerly wind of 12 miles per hour is assumed (Figure 1), then the plutonium within the $3 \mathrm{mCi} / \mathrm{km}^{2}$ contour must have had a particle size in excess of $10 \mu$ diameter. The particle size distribution of the plutonium influent to the stack is not available, although measurements are in progress to determine it (4). Moreover, stack monitoring from the start of plutonium operations in 1953 through 1968 indicate an integrated release of only $38 \mathrm{mCi}$ (7) of plutonium - far below what we found.

The May 11, 1969 fire can be exonerated as the source because the winds on that day (Figure 2) were almost directly opposite to the 
contamination pattern leaving the plant site (Figure 5). The detection of plutonium at $13 \mathrm{~cm}$ below the soil surface would further tend to rule out a significant contribution from this event. The September 11. 1957 fire can not be eliminated on the basis of the winds at the time of that fire (Figure 3). However the particle size of the dioxide from burning plutonium is estimated to be submicron (2). The sharp gradient and relatively short downwind extent of the contours in Figure 5 are not compatible with deposition of sub-micron particles.

There are several observations about the plutonium distribution which link the contamination to the leaking barrels. The plutonium laden oil from the corroded barrels contaminated the soil in and around the storage area. As the oil seeped underground or evaporated, strong gusty winds which occur predominantly from the west. resuspended the contaminated soil carrying it eastward. Because the efficiency for resuspending particulates decreases with Inwer wind velocities, the relatively light easterly winds would not distribute much contamination to the west of the plant site. The barrel storage area was in a region on Rocky Flats where the ground was mostly course rock and sand particles. If these 
particles are resuspended they would fall back to the ground rather quickly. The rapid decrease of the high level contours east of the plant site supports this view. Similarly the contamination did not concentrate in the creek ravines as do the fine particles of soil and alluvium .

It is interesting and probably meaningful that the surveys of the barrel storage area on the plant site suggested a southeasterly migration of the contamination. The contours off the plant site in Figure 5 also show a strong southerly component. 


\section{References}

(1) Report by the U.S. Atomic Energy Commission on the May 1.. 1969 Fire at the Rocky Flats Plant near Bouldex, colorado USAEC Press Release No. M-257. Tuesday, Novembex 18, 1969

(2) Report on the Dow Rocky Flats Fire: Implications of Plutonium Releases to the public Health and Safety Colorado Committee for Environmental Information. Subcommittee on Rocky Flats, Boulder, Colorado, January 13, 1970

(3) Dickson, C.R., and G. E. Start

Plutonium Releases to the Environment at Rocky Flats Memorandum to the Files, ESSA Research Laboratories, February 4, 1970

(4) Hammond, S.E.

Rocky Flats Division, The Dow Chemical Company Private Communication, 1970

(5) Harley, J.H., editor Manual of Standard Procedures Health and Safety Laboratory, USAEC Report NYO-4700,

August 1, 1970

(6) average of stratospheric ratios from HASP and stardust programs from $1958-1966$

(7) USAEC Press Release, No. N-22, Wednesday, February 18, 1970 


\section{Acknowledgments}

The soil sampling of the Rocky flats area was carried out with the full cooperation of Mr. Stanley E. Hammond, Industrial Hygiene Manager, Dow Chemical Co., Rocky Flats Plant. Two men from Mr. Hammond's group, Charles Thornberg and Duane Leonard. assisted us in the sampling over a two-day period.

We are grateful to the numerous property owners, and city and town officials who gave us permission to sample and helped us select suitable sites.

We wish to express our appreciation to Dr. John H. Harley. Director of the Health and Safety Laboratory, for his support in this work, for many useful discussions about the data, and for his help in preparing this report.

The preparation of the soil samples for analysis was carried out under the supervision of Gustave Farnham who was assisted by Aaron Frankel and John Weber.

Finally we acknowledge the contribution of Norton chu who developed the analytical and assay procedure for plutonium in soil. 
A P P E D I X 
ANALYTTCAL RESULTS: ROCKy Flats SOlis

\begin{tabular}{|c|c|c|c|c|c|c|c|}
\hline \multirow{2}{*}{$\begin{array}{l}\text { Map } \\
\text { Site }\end{array}$} & \multirow[b]{2}{*}{ Sample } & \multirow{2}{*}{$\begin{array}{l}\text { Sampling } \\
\text { date }\end{array}$} & \multirow{2}{*}{$\begin{array}{l}\text { depth } \\
(\mathrm{cm})\end{array}$} & \multirow{2}{*}{$\begin{array}{l}\text { area } \\
\left(\mathrm{cm}^{2}\right)\end{array}$} & \multicolumn{3}{|c|}{ dix drzed wt. $=\mathrm{kg}$} \\
\hline & & & & & total & rocks & s01 1 \\
\hline 1 & 1 & $2 / 11 / 70$ & $0-20$ & 966 & 38.29 & 17.60 & 20.69 \\
\hline 2 & 2 & $2 / 11 / 70$ & $0-20$ & 2050 & 44.58 & 20.20 & 24.38 \\
\hline 3 & 3 & $2 / 11 / 70$ & $0-20$ & 1003 & 35.94 & 14.38 & 21.56 \\
\hline 4 & 4 & $2 / 10 / 70$ & $0-20$ & 622 & 18.44 & & 18.44 \\
\hline 5 & 5 & $2 / 10 / 70$ & $0-15$ & 622 & 16.46 & 0.85 & 15.61 \\
\hline 6 & 6 & $2 / 10 / 70$ & $0-20$ & 928 & 33.83 & 8.73 & 25.10 \\
\hline
\end{tabular}

$\begin{array}{rrrrrrr}1 & 6 & 7 & 2 / 15 / 70 & 0-20 & 1003 & 27.29 \\ 1 & 6 & 8 & 2 / 14 / 70 & 0-5 & 929 & \\ & 6 & 9 & 2 / 14 / 70 & 5-8 & & \\ 6 & 10 & 2 / 14 / 70 & 8-10 & & \\ 6 & 11 & 2 / 14 / 70 & 10-13 & & \\ 6 & 13 & 2 / 14 / 70 & 13-15 & & \\ 7 & 14 & 2 / 14 / 70 & 15-18 & & \\ 8 & 15 & 2 / 15 / 70 & 0-20 & 622 & 19.19 \\ 8 & 16 & 2 / 10 / 70 & 0-5 & 622 & 2.31 \\ 8 & 17 & 2 / 10 / 70 & 5-20 & 622 & 17.48 \\ 8 & 18 & 2 / 15 / 70 & 0-6 & 81 & 0.39 \\ 8 & 19 & 2 / 15 / 70 & 6-9 & 81 & 0.22 \\ 8 & 20 & 2 / 15 / 70 & 9-13 & 46 & 0.22 \\ 8 & 21 & 2 / 15 / 70 & 13-20 & 62 & 0.87\end{array}$

Table A

anad. dpm per gram drieci soil (5) lab. IPA $\frac{\mathrm{Pu}-239}{0.0240 \pm 3 \%}$ $\frac{84-236}{0.0008+25 \%}$ $\mathrm{mCi}$ per $\mathrm{km}^{2}$ pu-239 pu-238 $0.0240 \pm 3 \% \quad 0.0008 \pm 25 \%$ $\begin{array}{ll}2.3 & 0.08\end{array}$

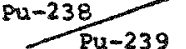
IPA $0.0295 \pm 3 \% \quad 0.0006 \pm 25 \%$ $0.0433 \pm 3 \% \quad 0.0012 \pm 20 \%$ $3.3 \quad 0.06$ IPA HASL (1) $0.0600 \pm 4 \% \quad 0.0019 \pm 5 \%$ $\begin{array}{lll}\text { IPA } & 0.0800 \pm 4 \% & 0.0013 \pm 8 \% \\ & 0.102 \pm 2 \% & 0.0020 \pm 15 \%\end{array}$

$4.2 \quad 0.12$
IPA $\quad 0.134 \pm 2 \%$ IPA $\quad 0.134 \pm 2 \%$ $0.0032 \pm 9 \%$

$\begin{array}{rll}8.0 & 0.25 & 0.031 \pm 6 \% \\ 10.7 & 0.18 & 0.016 \pm 9 \%\end{array}$
$\begin{array}{lll}13.6 & 0.27 & 0.016 \pm 9 \%\end{array}$ $15.1 \quad 0.36$ $0.020 \pm 15 \%$

HASL $\quad 18.7 \pm 4 \%$ HASL (1) $\quad 16.0 \pm 5 \%$ HASL $16.3 \pm 5 \%$ TLW(2) $22.4 \pm 3 \%$ TLW (2) $39.8 \pm 3 \%$ $0.318 \pm 4 \%$

men $16.6 \pm 2 \%$ $318 \pm 4 \%$ $15.6 \pm 2 \% \quad 0.285 \pm 4 \%$

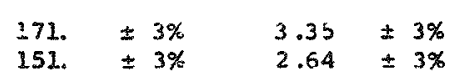
$1.72 \quad \mathrm{IPA}$ $2.64 \pm 3 \%$
$0.659 \pm 4 \%$ $35.8 \pm 3 \%$ $8.50 \pm 6 \%$ $0.180 \pm 6 \%$ 
Table A - cont'a

\begin{tabular}{|c|c|c|c|c|c|c|c|c|c|c|c|c|c|}
\hline \multirow{2}{*}{ int } & \multirow{2}{*}{ Sample } & \multirow{2}{*}{$\begin{array}{c}\text { Sampling } \\
\text { date }\end{array}$} & \multirow{2}{*}{$\begin{array}{l}\text { depth } \\
\text { com }\end{array}$} & \multirow{2}{*}{$\begin{array}{r}\text { area } \\
\left(\mathrm{cm}^{2}\right) \\
\end{array}$} & \multicolumn{3}{|c|}{ air aried we.-kg } & \multirow{2}{*}{$\begin{array}{l}\text { anal. } \\
\text { lab. }\end{array}$} & \multicolumn{2}{|c|}{ dom per qram dried soil } & \multicolumn{2}{|c|}{ mci_per $\mathrm{km}^{2}$} & \multirow{2}{*}{$\begin{array}{r}P_{u}^{238} \\
\quad P_{u}^{239} \\
\end{array}$} \\
\hline & & & & & tota1 & rocks & soil & & Pu-239 & Pu-238 & $\mathrm{Pu}-239$ & Pu-238 & \\
\hline 9 & 22 & $2 / 11 / 70$ & $0-20$ & 929 & 20.41 & 2.58 & 17.83 & $\begin{array}{l}\text { IPA } \\
\text { IPA }\end{array}$ & $\begin{array}{l}0.0328 \pm 3 \% \\
0.0266 \pm 4 \%\end{array}$ & $\begin{array}{l}0.0009 \pm 15 \% \\
0.0008 \pm 30 \%\end{array}$ & $\begin{array}{l}2.8 \\
2.3\end{array}$ & $\begin{array}{l}0.08 \\
0.07\end{array}$ & $\begin{array}{l}0.027 \pm 15 \% \\
0.030 \pm 30 \%\end{array}$ \\
\hline 10 & 23 & $2 / 12 / 70$ & $0-20$ & 966 & 22.99 & 1.65 & 21.34 & TLW & $0.0220 \pm 5 \%$ & $0.0063 \pm 10 \%$ & 2.2 & $0.62^{\prime 2}$ & $0.29 \pm 11 \%$ \\
\hline 11 & 24 & $2 / 10 / 70$ & $0-20$ & 622 & 17.60 & & 17.60 & IEA & $0.0420 \pm 4 \%$ & $0.0020 \pm 100 \%$ & 5.4 & 0.25 & $0.048 \pm 100 \%$ \\
\hline 12 & 25 & $2 / 9 / 70$ & $0=5$ & 622 & 2.98 & & 2.98 & $\begin{array}{l}\text { TLW } \\
\text { IPA }\end{array}$ & $\begin{array}{l}2.14 \pm 3 \% \\
1.83 \pm 3 \%\end{array}$ & $\begin{array}{l}0.0409 \pm 5 \% \\
0.0401 \pm 6 \%\end{array}$ & $\begin{array}{l}46.2 \\
39.5\end{array}$ & $\begin{array}{l}0.88 \\
0.86\end{array}$ & $\begin{array}{l}0.019 \pm 6 \% \\
0.022 \pm 7 \%\end{array}$ \\
\hline 12 & 26 & $2 / 9 / 70$ & $5-20$ & 622 & 14.28 & & 14.28 & TLW & $\begin{array}{l}0.0443+4 \% \\
0.0361 \pm 5 \%\end{array}$ & $\begin{array}{l}0.0053 \pm 11 \% \\
0.0010 \div 40 \%\end{array}$ & $\begin{array}{l}4.6 \\
3.7\end{array}$ & $\begin{array}{l}0.54 \\
0.10\end{array}$ & $\begin{array}{l}0.12 \pm 12 \% \\
0.028 \pm 40 \%\end{array}$ \\
\hline 12 & $27^{(4)}$ & $2 / 9 / 70$ & $0-10$ & & & & & & & & & & \\
\hline 13 & 28 & $2 / 11 / 70$ & $0-20$ & 1003 & 21.88 & 1.76 & 20.12 & TeA & $0.559 \pm 3 \%$ & $0.0104 \pm 11 \%$ & 50.5 & 0.94 & $0.019 \pm 12 \%$ \\
\hline 14 & 29 & $2 / 11 / 70$ & $0-5$ & 622 & 2.82 & & 2.82 & $\begin{array}{l}\text { TIW } \\
\text { IPB }\end{array}$ & $\begin{array}{l}0.517+5 \% \\
0.510 \pm 3 \%\end{array}$ & $\begin{array}{l}0.0113 \pm 16 \% \\
0.0105 \pm 10 \%\end{array}$ & $\begin{array}{l}10.5 \\
10.4\end{array}$ & $\begin{array}{l}0.23 \\
0.21\end{array}$ & $\begin{array}{l}0.022 \pm 16 \% \\
0.020 \pm 11 \%\end{array}$ \\
\hline 14 & 30 & $2 / 11 / 70$ & $5-20$ & 622 & 13.94 & & 23.94 & $\begin{array}{l}\text { TLW } \\
\text { IPA }\end{array}$ & $\begin{array}{l}0.100 \pm 4 \% \\
0.0332 \pm 5 \%\end{array}$ & $\begin{array}{l}0.0024 \pm 28 \% \\
0.0010 \pm 30 \%\end{array}$ & $\begin{array}{r}10.1 \\
3.4\end{array}$ & $\begin{array}{l}0.24 \\
0.10\end{array}$ & $\begin{array}{l}0.024+28 \% \\
0.030 \div 30 \%\end{array}$ \\
\hline 15 & 31 & $2 / 12 / 70$ & $0-20$ & 929 & 26.42 & & 26.41 & IPA & $0.138+4 \%$ & $0.0025+30 \%$ & 17.7 & 0.32 & $0.018 \pm 30 \%$ \\
\hline 16 & 32 & $2 / 13 / 70$ & $0-20$ & 622 & 14.52 & & 14.52 & $\begin{array}{l}\mathrm{TLW}(2) \\
\mathrm{IPA}\end{array}$ & $\begin{array}{l}0.483 \pm 3 \% \\
0.182 \pm 3 \%\end{array}$ & $\begin{array}{l}0.0113 \pm 9 \% \\
0.0039 \pm 15 \%\end{array}$ & $\begin{array}{l}50.7 \\
19.2\end{array}$ & $\begin{array}{l}1.19 \\
0.41\end{array}$ & $\begin{array}{l}0.023 \pm 1.0 \% \\
0.021 \pm 15 \%\end{array}$ \\
\hline 17 & 33 & $2 / 12 / 70$ & $0-20$ & 1003 & 36.56 & $12.20^{\circ}$ & 24.36 & IPA & $0.126 \pm 2 \%$ & $0.0021 \pm 17 \%$ & 47.0 & 0.23 & $0.017 \pm 17 \%$ \\
\hline 18 & 34 & $2 / 13 / 70$ & $0-20$ & 622 & 16.08 & & 16.08 & TLW & $0.0176 \pm 7 \%$ & $0.0005 \pm 99 \%$ & 2.0 & 0.06 & $0.028 \pm 100 \%$ \\
\hline 19 & 35 & $2 / 13 / 70$ & $0-20$ & 622 & 15.90 & & 15.90 & IPA & $0.0698 \pm 5 \%$ & $0.0017 \div 30 \%$ & 8.0 & 0.20 & $0.024+30 \%$ \\
\hline 20 & 36 & $2 / 12 / 70$ & $0-20$ & 1003 & 22.47 & & 22.47 & $I P A$ & $0.0262 \pm 4 \%$ & $0.0013 \div 30 \%$ & 2.6 & 0.13 & $0.050+30 \%$ \\
\hline $2 \dot{1}$ & 37 & $2 / 13 / 70$ & $0-20$ & 622 & 16.68 & & 16.68 & $\begin{array}{l}\text { IPA } \\
\text { IPA }\end{array}$ & $\begin{array}{l}0.0188 \div 4 \% \\
0.0253 \div 3 \%\end{array}$ & $\begin{array}{l}0.0004 \pm 100 \% \\
0.0007 \pm 20 \%\end{array}$ & $\begin{array}{l}2.3 \\
3.0\end{array}$ & $\begin{array}{l}0.05 \\
0.08\end{array}$ & $\begin{array}{l}0.021+100 \% \\
0.028 \pm 20 \%\end{array}$ \\
\hline 22 & 38 & $2 / 13 / 70$ & $0-20$ & 622 & 17.17 & & 17.17 & TLW & $0.0174+7 \%$ & $0.0010 \pm 8 \%$ & 2.2 & 0.13 & $0.057 \pm 48 \%$ \\
\hline 23 & 39 & $2 / 14 / 70$ & $0-20$ & 622 & 16.41 & & 16.41 & IPA & $0.0254 \pm 5 \%$ & $0.0006 \pm 100 \%$ & 3.0 & 0.07 & $0.024 \pm 100 \%$ \\
\hline 24 & 40 & $2 / 14 / 70$ & $0-20$ & 622 & 16.52 & & 16.52 & $I P A$ & $0.0220 \pm 7 \%$ & $0.0005 \pm 100 \%$ & 2.6 & 0.06 & $0.023 \pm 100 \%$ \\
\hline 25 & 41 & $2 / 14 / 70$ & $0-20$ & 622 & 1.6 .09 & & 16.09 & $I P A$ & $0.0205 \pm 6 \%$ & $0.0006 \pm 100 \%$ & 2.4 & 0.07 & $0.029+100 \%$ \\
\hline 26 & 42 & $2 / 12 / 70$ & $0-5$ & 622 & 3.55 & & 3.55 & TLW & $0.0343 \pm 4 \%$ & $0.0022 \pm 25 \%$ & 0.88 & 0.06 & $0.064 \pm 25 \%$ \\
\hline 28 & 63 & $2 / 12 / 70$ & $5-20$ & 622 & 17.61 & & 17.61 & $\begin{array}{l}\text { TLW } \\
\text { IPA }\end{array}$ & $\begin{array}{l}0.0136 \pm 7 \% \\
0.0085 \pm 6 \%\end{array}$ & $\begin{array}{l}0.0009 \pm 50 \% \\
0.0007 \pm 40 \%\end{array}$ & $\begin{array}{l}1.7 \\
1.1\end{array}$ & $\begin{array}{l}0.12 \\
0.09\end{array}$ & $\begin{array}{l}0.066 \pm 50 \% \\
0.082 \pm 40 \%\end{array}$ \\
\hline
\end{tabular}


Table A - cont'd

ANALYTICAL RESULTS: ROcky Flats Soils cont'd

\begin{tabular}{|c|c|c|c|c|c|c|c|c|c|c|c|c|}
\hline $\begin{array}{l}\text { Map } \\
\text { Site }\end{array}$ & Sample & $\begin{array}{l}\text { Sampling } \\
\text { date }\end{array}$ & $\begin{array}{l}\text { depth } \\
\text { (cm) }\end{array}$ & $\begin{array}{l}\operatorname{area} \\
\left(\mathrm{cm}^{2}\right)\end{array}$ & $\begin{array}{l}\text { air dried wt. } \\
\text { total rocks }\end{array}$ & $\frac{-\mathrm{kg}}{\text { soil }}$ & $\begin{array}{l}\text { anal. } \\
\text { lab. }\end{array}$ & $\begin{array}{c}\text { dpm per gram } \\
\text { pu-239 }\end{array}$ & $\begin{array}{c}\text { dried soil } \\
\text { pu-238 }\end{array}$ & $\begin{array}{l}\text { mei per } \\
\text { pu-239 }\end{array}$ & $\begin{array}{l}\mathrm{km}^{2} \\
\underline{P u-238}\end{array}$ & $\frac{10-238}{p u-239}$ \\
\hline 27 & 44 & $2 / 12 / 70$ & $0-5$ & 532 & 2.72 & 2.72 & $I P A$ & $0.0453 \pm 3 \%$ & $0.0010 \pm 20 \%$ & 0.83 & 0.02 & $0.022 \pm 20 \%$ \\
\hline 27 & 45 & $2 / 12 / 70$ & $5-20$ & 622 & 13.94 & 13.94 & IPA & $0.0107 \pm 5 \%$ & $0.0003 \pm 40 \%$ & 1.1 & 0.03 & $0.028 \pm 40 \%$ \\
\hline 28 & 46 & $2 / 13 / 70$ & $0-20$ & 622 & 20.69 & 20.69 & TLW & $0.0166 \pm 6 \%$ & $0.0013 \pm 35 \%$ & 2.5 & 0.20 & $0.078=35 \%$ \\
\hline 29 & 47 & $2 / 12 / 70$ & $0-10$ & 622 & 6.04 & 6.04 & IPA & $0.0422 \pm 3 \%$ & $0.0018 \pm 20 \%$ & 1.8 & 0.08 & $0.042 \pm 20 \%$ \\
\hline 29 & 48 & $2 / 12 / 70$ & $10-20$ & 622 & 13.90 & 13.90 & IPA & $0.0016 \pm 14 \%$ & $0.0007 \pm 30 \%$ & 0.16 & 0.07 & $0.44 \pm 30 \%$ \\
\hline 30 & 49 & $2 / 13 / 70$ & $0-20$ & 678 & 22.08 & 22.08 & TLW & $0.0190 \pm 7 \%$ & $0.0010 \pm 57 \%$ & 2.8 & 0.15 & $0.053 \pm 57 \%$ \\
\hline 31 & 50 & $2 / 13 / 70$ & $0-20$ & 622 & 17.44 & 17.44 & $I P A$ & $0.0170 \pm 4 \%$ & $0.0005 \pm 30 \%$ & 2.1 & 0.06 & $0.029 \pm 30 \%$ \\
\hline 32 & 51 & $2 / 23 / 70$ & $0-20$ & 622 & 21.34 & 21.34 & $\begin{array}{l}\text { TLW } \\
\text { TLW (2) } \\
\text { IPA }\end{array}$ & $\begin{array}{l}0.0192 \pm 6 \% \\
0.734 \pm 2 \% \\
0.0153 \pm 5 \%\end{array}$ & $\begin{array}{l}0.0022 \pm 26 \% \\
0.0134 \pm 7 \% \\
0.0006 \pm 100 \%\end{array}$ & $\begin{array}{l}7.0 \\
113 \\
2.4\end{array}$ & $\begin{array}{l}0.34 \\
2.1 \\
0.09\end{array}$ & $\begin{array}{l}0.11 \pm 26 \% \\
0.018 \pm 7 \% \\
0.039 \pm 100 \%\end{array}$ \\
\hline 33 & 52 & $2 / 13 / 70$ & $0-20$ & 622 & 16.94 & 16.94 & $I P A$ & $0.0144 \pm 4 \%$ & $0.0005 \pm 30 \%$ & 1.8 & 0.06 & $0.035 \pm 30 \%$ \\
\hline
\end{tabular}

(1) sodiur carbonate fusion

(2) plutonium results not used in averaging

(3) calculated from estimates of soil density

(4) sample not analyzed

(5) 100 gram aliquot of air dried soil leached by HASL method 
ANALYTICAL RESULTS: Reference SOlis

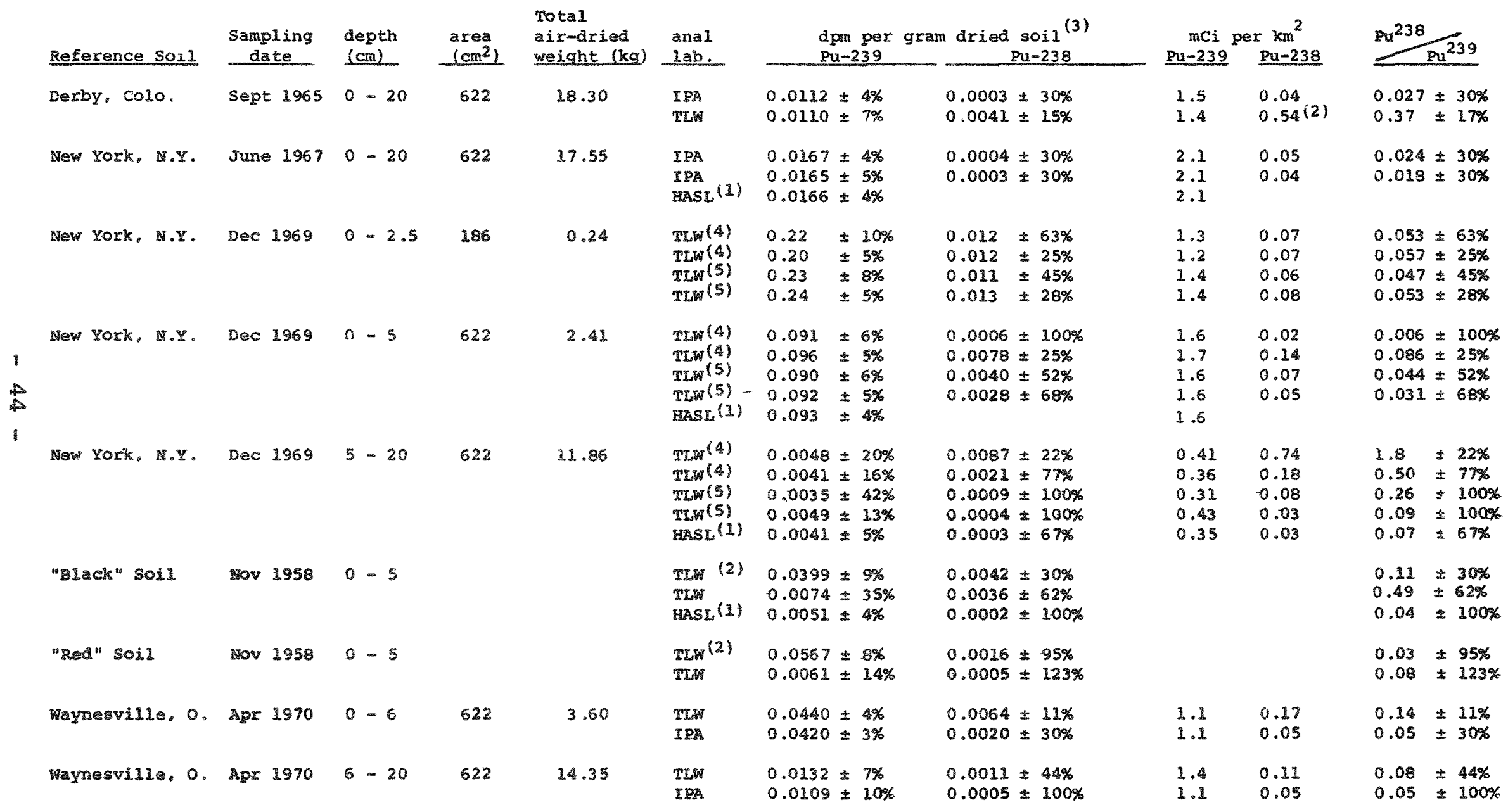

(1) Sodium carbonate fusion

(2) value sumpect

(3) 100 gram aliquot of air dried soil leached by kast method

(4) " " " " " " " " " " " " " " " " " " "

(5) " " " " " $"$ completely dissolved in acid and HF, 